\title{
Stereotip Mahasiswa IAIN Pontianak terhadap Agama Baha'i
}

\author{
Samsul Hidayat \\ IAIN Pontianak - Kalimantan Barat \\ camcul4@gmail.com
}

\begin{abstract}
In general, people of West Kalimantan have slight understanding relating to the existence of Baha'i religion. They built some stereotypes and judgments based on interaction and daily communication with Baha'i followers. This research focuses on how the under-graduate student of State Institute of Islamic studies (IAIN) Pontianak perceive and understand Baha'i during the class of Interreligious Communication (Komunikasi Lintas Agama). Dealing with the under-graduate student of the seventh semester, this research aims to analyze such paradigm construction through Thung Ju Lan idea of "foreigners" and "cultural differences". This research found that students have constructed their perception on Baha'i through theological denial or cultural assessment of other religious tradition.

[Secara umum penduduk Kallimantan Barat memiliki pemahaman yang tidak mendalam terkait dengan agama Baha'i. Mereka membangun prasangka, stereotip, dan keyakinan sendiri tentang Baha'i, berdasar pada interksi dan komunikasi sehari-sehari dengan pemeluk Baha'i. Penelitian ini fokus pada bagaimana mahasiswa Institut Agama Islam Negeri (IAIN) Pontianak membangun pandangan dan pemahaman mereka terhadap Baha'i dalam kelas matakuliah Komunikasi Lintas Agama. Meneliti para mahasiswa yang duduk di semester ke-7, penelitian ini bertujuan untuk menganalisis bagunan kerangka berpikir tersebut melalui konsepnya Thung Ju Lan, foreigners and cultural differences. Penelitian ini menemukan bahwa sebagian mahasiswa membangun persepsi teologis terkait agama Baha'i sebagai "sesuatu yang semestinya ditolak" dan "tidak sesuai dengan agama Islam.]
\end{abstract}

Keywords: stereotypes, Baha'i, Inter-religious communication. 


\section{Pendahuluan}

Agama Baha'i merupakan salah satu agama besar dunia yang memiliki penganut di Indonesia. Pada umumnya masyarakat banyak yang belum mengetahui dan memahami keberadaan dan ajaran agama Baha’i ini, sehingga memunculkan penilaian-penilaian tertentu berdasarkan persepsi yang terbangun sesuai dengan komunikasi dan interaksi masyarakat kepada pemeluk agama tersebut. Tidak terkecuali dengan mahasiswa Institut Agama Islam Negeri (IAIN) Pontianak yang semuanya beragama Islam. Mereka memiliki stereotip tertentu terhadap agama Baha’i akibat minimnya pengetahuan dan interaksi mereka dengan ajaran dan pengikut agama Baha’i khususnya di Kalimantan Barat. Apa yang menjadi representasi pengetahuan, pemahaman, dan penilaian mahasiswa IAIN Pontianak terhadap agama dan pemeluk Baha'i mempengaruhi perasaan mereka terhadap kelompok tersebut. ${ }^{1}$

Menurut Thung Ju Lan, ada beberapa kategori dasar yang menjadi akar dari munculnya stereotip: kategori orang asing, jenis pekerjaan, orientasi politik, dan perbedaan budaya. ${ }^{2}$ Meskipun Ju Lan merumuskan kategorisasi stereotip mengacu pada peristiwa diskiriminasi terhadap orang Cina di Indonesia, namun kategorisasi tersebut dapat digunakan untuk melihat secara generalistik penyebab dan akibat dari stereotip.

Salah satu penyebab utama dari munculnya stereotip adalah adanya istilah orang asing atau orang luar, di mana salah satu kelompok menempatkan orang lain sebagai bukan kelompoknya atau golongannya. Dalam sejarah Indonesia, mereka yang dianggap orang asing sebagai golongan Timur Asing (Cina, Arab, India), sementara orang lokal disebut sebagai penduduk asli, atau istilah Belanda diketegorikan sebagai inlanders.

${ }^{1}$ Gudykunst, W. B., \& Kim, Y. Y, Communicating with Strangers: An Approach to Intercultural Communication (New York: McGraw-Hill, 1997), 112.

2 Thung Ju Lan, "Etnis Tionghoa dalam Pemberitaan Media: Menghapus Prasangka dan Diskriminasi Etnis dalam Pemberitaan Media Cetak"(Makalah untuk Seminar Yayasan KIPPAS, Novotel Soechl Medan, 21 Maret 2002).

56| Samsul Hidayat - Stereotip Mahasiswa IAIN Pontianak terhadap Agama Baha’i 
Itulah sebabnya sampai sekarang kita masih berhadapan dengan persoalan penduduk asli dan penduduk pendatang.

Dalam konteks yang lain, istilah orang asing dapat dihubungkan dengan istilah "agama resmi" atau "agama yang diakui". Dalam praktek keberagamaan di masyarakat, penggunaan istilah agama resmi atau agama yang diakui pada akhirnya membentuk stigma bahwa hanya agama yang diakui yang boleh eksis di Indonesia. Akibatnya agama-agama besar dunia yang tidak termasuk ke dalam kategori agama yang diakui dianggap tidak legal dan sebagainya.

Pembentukan streotip tidak jarang melibatkan adanya kepentingan tertentu dibalik stereotip tersebut. Memang terdapat kecenderungan bahwa sebagian besar stereotip terhadap agama Baha’i memiliki konotasi negatif karena minimnya pengetahuan terhadap eksistensi dan ajaran agama Baha'i tersebut. Akibatnya penggambaran terhadap kelompok atau agama Baha'i dan pemeluknya tidak jarang dilakukan secara stereotipikal atau terkesan merendahkan.

Begitupun apa yang dialami oleh Mahasiswa IAIN Pontianak khususnya pada Fakultas Ushuluddin, Adab, dan Dakwah. Mereka memiliki kecenderungan stereotip terhadap agama Baha’i. Hal ini dapat dilihat dari hasil diskusi dan wawancara peneliti kepada mahasiswa pada saat mengampu mata kuliah Komunikasi Lintas Agama di Jurusan Komunikasi dan Penyiaran Islam semester VII tahun ajaran 2015-2016. Pada salah satu tema perkuliahan yang mengangkat agama Baha'i, mahasiswa diperkenalkan baik secara teoritis maupun lapangan konsep ajaran dan komunitas pemeluk Baha'i di Kota Pontianak. Sebelum sesi diskusi dan outing class dilakukan, peneliti melakukan pre-test untuk menelusuri tingkat pengetahuan dan pemahaman mahasiswa terhadap agama Baha'i sehingga dapat diketahui kategori stereotip mahasiswa IAIN Pontianak terhadap agama Baha’i tersebut. Bentuk-bentuk stereotip yang muncul pada mahasiswa IAIN Pontianak akan mempengaruhi bagaimana 
sebuah penilaian terhadap mahasiswa dari kelompok yang dikenai stereotip. $^{3}$

Untuk itu penelitian tentang bagaimana stereotip mahasiswa IAIN Pontianak terhadap agama Baha'i menjadi penting dalam upaya meningkatkan pengetahuan dan pemahaman mahasiswa terhadap eksistensi dan ajaran agama selain Islam demi terwujudnya mahasiswa yang berpikiran terbuka dan toleran.

Penelitian ini menggunakan tipe penelitian deskriptif dengan metode analisis kualitatif. Melalui studi lapangan, peneliti mengerjakan semua proses penelitian dan terlibat langsung dalam proses tersebut. Keterlibatan peneliti dimaksudkan untuk lebih memahami konteks masalah dan tema yang dibahas, selain karena memang penelitian ini dilakukan pada aktivitas perkuliahan, baik dalam maupun luar kelas. ${ }^{4}$ Data diperoleh melalui observasi lapangan baik di lokasi kelas maupun luar kelas dan wawancara mendalam (indept-interview) dalam sebuah diskusi terfokus dan penyebaran kuesioner. Wawancara atau diskusi terfokus dilakukan karena beberapa pertimbangan, yaitu: topik yang diangkat bersifat kompleks dan membutuhkan pemahaman yang mendalam, serta menggali pengetahuan yang luas dari informan.

Peneliti menggunakan metode kualitatif dalam menganalisis data penelitian ini. ${ }^{5}$ Metode ini digunakan karena menyajikan secara langsung hakekat hubungan antara peneliti dan informan, dan metode ini lebih peka dan lebih dapat menyesuaikan diri dengan banyak penajaman pengaruh bersama dan terhadap pola-pola nilai yang dihadapi. ${ }^{6}$ Berhubung analisa kualitatif lebih menekankan kepada data, ${ }^{7}$ maka untuk menyederhanakan

3 Jennings Bryant and Dolf Zillmann, Media Effect: Advances in Theory and Research (London: L. Erlbaum, 2002), 102-103.

4James Fox, "Dimensi Waktu dalam Penelitian Sosial: Suatu Studi Kasus di Pulau Roti", dalam Aspek. Manusia dalam Penelitian Masyarakat, ed. Koentjaraningrat dan Donald K. Emmerson (Jakarta: Gramedia, 1982), 56.

5J. Spradley, Metode Etnografi (Yogyakarta: Tiara Wacana, 1997).

${ }^{6}$ Lexy Moloeong, Metodologi Penelitian Kualitatif (Bandung: Remaja Rosdakarya, 2002).

${ }^{7}$ Bambang Suparyogo dkk, Metodologi Penelitian Agama (Jakarta: Grafika, 2001).

58 Samsul Hidayat - Stereotip Mahasiswa IAIN Pontianak terhadap Agama Baha’i 
seluruh data yang terkumpul sehingga dapat disajikan dalam suatu susunan yang sistematis, dilakukan proses pengorganisasian dan pengurutan data ke dalam pola, kategori, dan satuan uraian dasar sehingga dapat ditemukan tema dan dapat dirumuskan hipotesis kerja seperti yang disarankan oleh data. Pada penelitian ini data hasil wawancara dan kuesioner dipolakan dalam satu kategori tertentu yaitu, pernyataan dan pemikiran mahasiswa yang berhubungan dengan agama Baha'i untuk peneliti tentukan bentuk stereotip mahasiswa terhadap agama tersebut.

\section{Sekilas tentang Agama Baha'i}

Agama Baha'i menganut faham monoteistik yang menekankan persatuan spiritual umat manusia. Agama ini bersifat independen dan bukan merupakan aliran atau sempalan agama tertentu. Agama Baha'i dibawa dan didirikan oleh Baha'ullah asal Persia pada abad 19. Tujuan dari agama ini menyatukan agama dan umat manusia dalam sebuah prinsipprinsip keesaan Tuhan, dan mewujudkan tarnsformasi rohani dalam kehidupan manusia.

Penganut Baha’i menyakini dan mempercayai kebenaran agama-agama yang sudah turun sebelumnya seperti Yahudi, Kristen, dan Islam. Ini disebabkan karena mereka berprinsip bahwa setiap agama mengajarkan perdamaian dan keselarasan baik dilingkungan keluarga, masyarakat, dan bahkan dunia. Salah satu upaya menemukan dan menjaga perdamaian adalah dengan mengutamakan melihat pribadi secara ruhani atau batin, bukan pada fisik atau penampakan luar. Dengan demikian kehidupan rohani harus selalu ditingkatkan, termasuk kehidupan ekonomi dan sosial budaya secara seimbang, tanpa berlebihan atau kekurangan.

Beberapa prinsip ajaran Baha'i di antaranya menyakini adanya Tuhan yang Maha Esa. Sebagai bukti bahwa Tuhan itu ada, dapat dilihat pada fakta bahwa manusia tidak memiliki kemampuan menciptakan dirinya sendiri, bahkan sebaliknya, pencipta dan perancangnya pun bukan dirinya sendiri. ${ }^{8}$ Selain itu, agama Baha’i mengajarkan kesatuan kemanusiaan,

8 Majelis Rohani Nasional Baha’i Indonesia, Agama Babai (Jakarta: Majelis Rohani Nasional Baha'i Indonesia, 2013), 5. 
kebebasan dalam menjalankan keyakinan, dan menjalankan kehidupan yang suci dan murni.

Di situs www.bahai.org sebagai laman resmi agama Baha’i diterangkan pada awalnya ada seorang pemuda bernama Ali Muhammad yang bergelar Bâb berasal dari kota Shiraz Iran mengaku sebagai utusan tuhan, dan pada 23 Mei 1844 menyampaikan akan datangnya seorang pembawa wahyu. Namun karena faham Bâb dianggap menyimpang dari ajaran mainstream, maka otoritas Persia menangkap dan mengeksekusi Bâb di lapangan kota Tabriz pada tanggal 9 Juli 1850.

Beberapa tahun setelah kematian Bâb, pada tahun 1863 muncullah Husen Ali atau Baha'ullah, seorang ningrat Persia (lahir 1817) yang menyatakan dirinya secara terbuka sebagai orang yang dijanjikan kedatangannya di muka bumi oleh Sang Bâb. Pengakuan Baha'ullah lagilagi menimbulkan keresahan dan penolakan dari beberapa pemimpin agama sehingga akhirnya Baha'ullah ditahan di beberapa tempat seperti di Konstantinopel, Adrianopel, dan Acre di Israel pada tahun 1868.

Selama hidupnya, Baha'ullah menulis beberapa karya yang diyakini sebagai wahyu yang berasal dari Tuhan, dan kemudian menyampaikan ajaran tersebut kepada umat manusia, sampai masa wafatnya tahun 1892 di Bahji, Israel. Sebelum meninggal, Baha'ullah menunjuk salah satu putranya, Abdul Baha' sebagai penerus dan penafsir yang sah ajaran Baha’ullah. Ajaran Baha'i kemudian berkembang pesat sejak Abdul Baha' melakukan perjalanan ke beberapa negara besar seperti Mesir, Eropa, dan Amerika.

Setelah Abdul Baha', tongkat penerus selanjutnya berganti ke cucu Abdul Baha', yaitu Shoghi Effendi Rabbani yang dipanggil sebagai Wali Agama. Selama menjadi penerus Baha'i, Shoghi banyak menterjemahkan ajaran Baha'ullah dan Abdul Baha' ke dalam bahasa Inggris yang berdampak pada penyebaran agama Baha'i secara luas di seluruh dunia. Setelah masa Soghi Effendi, penyebaran ajaran Baha’i dikelola dalam sebuah lembaga internasional yang disebut dengan Balai Keadilan Sedunia. 
Pada tahun 1878 ajaran Baha'i sampai ke Indonesia melalui pedagang yang bernama Jamal Efendi dan Mustafa Rumi. Kedatangan mereka selalu disambut dengan baik oleh masyarakat dan pembesar, karena selain mengajarkan kedamian dan harmoni, penyebar Baha'i melakukan kegiatan sosial yang membuat penguasa hormat dengan mereka. Beberapa daerah yang pernah dikunjungi oleh penyebar Baha'i ini seperti Batavia (Jakarta), Surabaya, Bali, Makassar, Parepare, dan Bone.

Selama perjalanan menyebarkan ajaran Baha'i, Jamal Efendi dan Mustafa Rumi selalu mendapat perlakukan baik terutama oleh para Raja dan permaisuri beberapa kerajaan, di mana mereka diminta untuk tinggal dan berdiam beberapa waktu, melakukan pertemuan dan diskusi tentang kerohanian dan prinsip-prinsip kenegaraan. Bahkan seperti diterangkan dalam The Baha'i Magazine,Mustafa Rumi diminta oleh Raja Sulawesi untuk membuat pedoman tentang asas-asas dan dasar negara serta buku pelajaran Bahasa Arab. Tentu saja hal tersebut sangat diapresiasi oleh Mustafa Rumi dan Jamal Efendi sebagai sebuah peluang untuk menyebarkan ajaran-ajaran universal Baha'i. Selanjutnya agama Baha’i terus berkembang dari satu wilayah ke wilayah lain, seperti di Jawa Tengah, Jawa Barat, Jawa Timur, Sumatera, Sulawesi, Kalimantan, dan daerahdaerah lainnya.

Gambaran tentang eksistensi agama Baha’i dalam konteks Indonesia pernah diteliti dan dipresentasikan oleh Nuhrison M. Nuh, dengan judul Eksistensi Agama Baha'i di Beberapa Daerah di Indonesia:Studi Kasus di Pati (Jateng), Banyunangi/Malang (Jatim), Palopo (Sulsel) dan Bandung (Jabar). Nuhrison menggambarkan bahwa eksistensi agama Baha'i di beberapa daerah tertentu sudah cukup dikenal sehingga masyarakat lebih mudah memahami paham dan ajaran tersebut. Sementara di daerah yang belum mengenal agama Baha'i, perkembangan agama tersebut mengalami banyak hambatan. Salah satu hambatan yang dihadapi oleh pemeluk Baha'i adalah masalah pelayanan hak-hak sipil yang belum diberikan sepenuhnya. Sementara masyarakat pada umumnya masih memahami bahwa agama 
Baha'i adalah salah satu agama yang tidak diakui oleh pemerintah. ${ }^{9}$ Namun karena terbatasnya penelitian yang dilakukan oleh Nuhrison, dia tidak dapat menggambarkan konteks wilayah Kalimantan Barat, di mana masyarakatnya belum banyak yang mengenal dan mengetahui ajaran dan eksistensi agama tersebut.

\section{Pengakuan Pemerintah terhadap Agama Baha'i}

Dalam upaya mendapat pengakuan dari pemerintah, komunitas agama Baha'i melakukan langkah-langkah strategis yang diharapkan dapat memberikan penjelasan kepada masyarakat Indonesia bahwa agama Baha’i bukan merupakan salah satu aliran, faham, atau sempalan dari agama tertentu seperti Islam atau Kristen.

Melalui surat dari Kementerian Agama RI yang ditandatangani Sekretaris Jenderal, Bahrul Hayat, nomor SJ/B.VII/1/HM.00/675/2014 tanggal 24 Februari 2014 sebagai jawaban dari surat Direktur Jenderal Kependudukan dan Catatan Sipil Kementerian Dalam Negeri nomor 472.2/5435/DUKCAPIL tanggal 11 Juni 2013 perihal Penjelasan mengenai Penganut Baha'i, dijelaskan beberapa hal sebagai berikut:

1. Bahwa berdasarkan kajian Badan Litbang Agama dan Diklat Keagamaan Kementerian Agam RI, Baha'i adalah suatu agama dan bukan merupakan aliran dari suatu agama. Oleh karenanya, sesuai dengan ketentuan Pasal 29, Pasal 28E, serta Pasal 28I Undang-Undang Dasar 1945 agama Baha'i dapat hidup di Indonesia dan siapa saja warga Negara Indonesia berhak memeluk agama Baha'i serta beribadat menurut ajaran agamanya.

2. Berdasarkan ketentuan Penjelasan Undang-Undang Nomor 1/PNPS/1965, agama Baha'i seperti halnya agama-agama diluar 6 agama (Islam, Kristen, Katholik, Hindu, Budha, dan Khonghucu)

\footnotetext{
${ }^{9}$ M. Nuhrison, "Eksistensi Agama Baha'i, Tao, dan Sikh di Indonesia” (Makalah Seminar Penelitian yang diadakan oleh Puslitbang Kehidupan Keagamaan Badan Litbang dan Diklat, Kementerian Agama RI, Jakarta: 22 September 2014).
} 
mendapat jaminan penuh dari negara, serta dibiarkan adanya sepanjang tidak melanggar ketentuan peraturan perundang-undangan.

3. Dalam hal layanan administrasi kependudukan, sesuai ketentuan Undang-Undang Nomor 23 tahun 2006 jo UU nomor 24 tahun 2013 tentang Administrasi Kependudukan, umat Baha'i berhak mendapatkan layanan kependudukan dan pencatatan sipil sebagaimana warga negara Indonesia lainnya, dengan pembatasan tertentu sebagaimana yang berlaku bagi umat beragama di luar 6 agama dan kepercayaan terhadap Tuhan Yang Maha Esa.

Berdasarkan hal tersebut di atas, menurut hemat kami penganut agama Baha'i berhak mendapatkan layanan kependudukan dan pencatatan sipil sesuai dengan peraturan perundang-undangan yang berlaku.

Di surat yang lain, Kementerian Agama RI melalui Pgs. Kepala Badan Litbang dan Diklat, Machasin, dengan nomor surat BD/BA.01/1120/2014 tanggal 26 Mei 2014 memberikan penjelasan keberadaan Baha'i di Indonesia kepada Sekretaris Jenderal Kementerian Agama RI yang mengacu pada surat yang dibuat oleh Menteri Dalam Negeri Republik Indonesia Nomor: 450/1581/SJ tanggal 27 Maret 2014 dengan memberikan beberapa penjelasan sebagai berikut:

1. Bahwa Undang-Undang Dasar Negara RI Tahun 1945 telah mengatur kebebasan beragama sebagaimana tercantum dalam Pasal 29 ayat (2), Pasal 28 E ayat (1), dan Pasal 28I ayat (2). Sementara itu terkait dengan jaminan bagi keberadaan penganut agama di luar enam agama, ditegaskan dalam Penjelasan Undang-Undang No 1/PNPS/1965 tentang Pencegahan Penyalahgunaan dan/atau Penodaan Agama.

2. Baha'i merupakan agama yang tumbuh dan berkembang di dunia internasional selain agama Kristen, Islam, Hindu, Buddha, Khonghucu, Yahudi, Shinto, dan Zoroaster. Pemeluk agama Baha’i di Indonesia saat ini tersebar di beberapa provinsi antara lain Sumatera Utara (Medan), DKI Jakarta (Jakarta Pusat, Jakarta Barat, Jakarta Selatan), Jawa Barat (Bekasi, Depok, Bogor, dan Bandung), Jawa 
Tengah (Semarang, Pati, Klaten, Bojonegoro, Ponorogo dan Rembang), Jawa Timur (Surabaya, Malang, Banyuwangi dan Tulungagung), Sulawesi Selatan (Makassar dan Palopo), Sulawesi Utara (Manado), dan Bali (Denpasar).

3. Belum diketahui secara pasti berapa jumlah penganut Baha’i di Indonesia. Mereka hidup berbaur dengan masyarakat dan tidak menunjukkan karakteristik tertentu, baik dalam penampilan fisik maupun tata cara beribadat, sehingga tidak mudah dikenali secara khusus. Di samping itu, di beberapa daerah, penganut Baha'i masih enggan untuk menunjukkan identitasnya sebagai penganut Baha'i karena pengalaman pahit di masa lalu ketika dianggap sebagai pengikut aliran menyimpang. Namun demikian, dari hasil pemantauan singkat kami pada bulan April 2014, dapat disebutkan perkiraan jumlah penganut Baha'i di beberapa daerah antara lain di Jakarta sekitar 100 orang, di kota dan Kabupaten Bandung 50 orang, di Palopo 80 orang, di Medan sekitar 100 orang, di Pati 23 orang, di Bekasi 11 orang, di Surabaya 98 orang, dan di Kota Malang ada 15 orang, di Kabupaten Malang 15 orang, dan di Banyuwangi sekitar 220 orang.

4. Agama Baha’i mengajarkan beberapa prinsip moral antara lain persatuan umat manusia, persamaan hak antara laki-laki dan perempuan, penghapusan prasangka buruk, kesetaraan antar sesama manusia, perdamaian dunia, kebenaran semua agama, mencari kebenaran, tidak terlibat sebagai pengurus partai politik, penghapusan kemiskinan dan kekayaan yang berlebihan, serta ajaran moral untuk setia kepada pemerintah. Ajaran moral yang disebut terakhir, yaitu kesetiaan kepada pemerintah, menyebabkan penganut Baha'i hampir tidak pernah terlibat dalam aksi atau gerakan-gerakan yang menentang kebijakan pemerintah.

5. Berdasarkan hal tersebut, maka dalam rangka pemenuhan hak-hak sipil penganut Baha’i diperlukan pernyataan dari Menteri Agama bahwa Baha'i benar-benar merupakan agama yang dipeluk oleh sebagian penduduk Indonesia. 
Melalui beberapa surat yang dikeluarkan oleh lembaga pemerintah terutama dari Kementerian Agama yang bertanggung jawab dalam membina dan menfasilitasi kehidupan keagamaan di Indonesia, maka agama Baha'i jelas merupakan salah satu agama selain 6 agama yang diakui keberadaannya di Indonesia.

Secara hukum, sebenarnya umat agama Baha’i dapat melakukan sosialisasi atas eksistensi atau kehadiran agama mereka di masyarakat. Namun untuk menjaga ketertiban dan menghindari keresahan di masyarakat yang mudah sensitif mendengar ajaran-ajaran yang terlihat baru, komunitas Baha'i lebih memilih menjalankan keyakinan mereka dengan lebih tertutup dan tidak bersifat misi. Namun berdasarkan pengalaman peneliti bersama komunitas Baha'i di Pontianak Kalimantan Barat, komunitas Baha'i sebenarnya sangat ramah dan terbuka dengan siapapun yang ingin berhubungan dengan mereka. Meskipun tetap mengedepankan kehati-hatian, salah satu prinsip ajaran mereka yaitu menghindari prasangka. Mereka sangat senang dan membuka diri untuk setiap bentuk komunikasi dan diskusi yang berhubungan baik dengan kehidupan sosial maupun keagamaan.

\section{Bentuk Stereotip Mahasiswa terhadap Agama Baha'i}

Untuk melihat dan menentukan bentuk stereotip mahasiswa IAIN Pontianak terhadap agama Baha'i, peneliti menelusuri pemahaman awal mahasiswa terhadap beberapa aspek, yaitu: pembawa ajaran Baha'i, konsep ketuhanan, konsep kenabian, konsep kitab suci, konsep tempat ibadah, dan konsep hari besar. Aspek-aspek yang diteliti ini mengacu pada kategorisasi yang pada umumnya dipahami sebagai syarat dalam penentuan sebuah agama.

Seperti yang dijelaskan Thung Ju Lan tentang beberapa kategori dasar yang menjadi akar dari munculnya stereotip seperti kategori "orang asing", jenis pekerjaan, orientasi politik, dan perbedaan budaya. Kategori stereotip yang dirumuskan Thung Ju Lan sebenarnya mengaju pada peristiwa 
diskiriminasi terhadap orang Cina di Indonesia, ${ }^{10}$ namun peneliti menggunakan salah satu ketegori yang digunakan untuk mengungkap bentuk stereotip mahasiswa terhadap agama Baha'i, yaitu kategori "orang asing dan perbedaan budaya."

Istilah "orang asing" atau orang luar yang menjadi penyebab munculnya stereotip disebabkan karena salah satu kelompok menempatkan orang lain sebagai bukan kelompoknya atau golongannya. Penyebutan orang asing, memang tidak selalu menggunakan kata yang persis sama, seperti kata "orang asing", namun indikatornya dapat dilihat dari pernyataan atau kalimat yang mengarah pada penjelasan bahwa orang atau kelompok tertentu bukan bagian dari komunitas mereka. Stereotip mahasiswa IAIN Pontianak pada kategori "orang asing" atau orang yang ditempatkan diluar faham kelompoknya sendiri, mengambil bentukbentuk pemikiran yang menunjukkan penolakan pada ajaran atau komunitas Baha'i, seperti menyangkal bahwa tuhan bisa mewujud ke dalam diri manusia (Baha'ullah) dan tidak menyetujui faham kesatuan agama.

Adapun stereotip dalam bentuk perbedaan budaya merupakan bentuk penilaian yang berdasarkan persepsi terhadap kelompok di mana orang tersebut dapat dikategorikan. ${ }^{11}$ Perbedaan budaya dalam konteks penelitian ini adalah penilaian terhadap tradisi agama lain yang dihubungkan dengan pokok-pokok tradisi agamanya sendiri. Beberapa bentuk penilaian mahasiswa dalam konteks perbedaan budaya seperti: apakah agama Baha'i memiliki tuhan; siapa namanya; apakah Baha'ullah benar-benar utusan tuhan; apakah ada mukjizatnya; apakah kitab suci nya benar-benar merupakan wahyu tuhan; apakah Baha’i mengajarkan salat atau puasa; dan apakah salat atau puasanya sama dengan salat dan puasa dalam Islam. Stereotip dengan indikator penilaian seperti ini, menghubungkan sebuah kepastian pada satu agama tertentu dengan mencari kesesuaian pada agamanya sendiri. Dalam hal ini mahasiswa

${ }^{10}$ Ju Lan, "Etnis Tionghoa Dalam Pemberitaan Media".

${ }^{11}$ Stephen P. Robbins and Timothy A. Judge, Organizational Behavior (Prentice Hall, 2010).

66| Samsul Hidayat - Stereotip Mahasiswa IAIN Pontianak terhadap Agama Baha’i 
meyakini bahwa untuk disebut sebagai sebuah agama, suatu ajaran atau faham harus memenuhi beberapa persyaratan seperti keyakinan pada adanya tuhan, utusan, kitab suci, dan ajarannya. Jika salah satu kategori tadi tidak terdapat dalam sebuah faham, maka faham tersebut dinilai bukan merupakan sebuah agama.

Berikut ini merupakan bentuk stereotip mahasiswa yang dilihat dari pemahaman mereka terhadap konsep-konsep pokok agama Baha'i:

\section{Konsep Ketuhanan}

Agama Baha'i menganut konsep Ketuhanan Yang Maha Esa, Tuhan itu satu, yang berarti Tuhan dari semua agama itu sama dan satu. Apapun bentuk tuhan dari agama lain, baik itu dewa, patung, dan lain sebagainya menurut agama Baha'i hanyalah sebagai media yang merupakan bentuk perwujudan manusia untuk menghadirkan Tuhan dalam dirinya, namun Tuhan yang disembah tetap Tuhan yang satu, yaitu Tuhan Yang Maha Esa.

Hampir semua mahasiswa bereaksi keras dan menilai bahwa konsep ajaran Baha'i di atas adalah sesat. Mahasiswa tidak bisa memahami bagaimana semua agama adalah sama dan satu. Mahasiswa menilai bahwa agama Baha'i adalah ajaran yang mencoba menyatukan semua agama menjadi satu, dan hal ini sama sekali tidak bisa dibenarkan. Jika tuhan semua agama adalah satu, mahasiswa bertanya kembali mengapa tuhan harus membiarkan banyaknya agama yang eksis di muka bumi. Ajaran Baha'i dianggap sebagian kecil mahasiswa sebagai "agama olokan", dalam arti tidak mungkin tuhan semua agama adalah tuhan yang sama.

Dalam kepercayaan agama Baha'i sendiri, penamaan Tuhannya, mereka tidak memberikan nama khusus untuk menyebut Tuhannya, sebab esensi agama Baha'i adalah Tuhan itu satu atau esa. Hampir semua mahasiswa menilai bahwa agama Baha’i membawa ajaran yang tidak jelas, karena mana mungkin tuhan tidak memiliki nama, bahkan nama tuhan bisa disebut sesuai selera atau keinginan seseorang sesuai keyakinan agama masing-masing. Bagi yang beragama Islam atau Kristen dapat menyebut tuhannya dengan nama Allah. Bagi penganut Hindu dapat menyebut Sang Hyang Widi, sementara pemeluk Buddha menyebut Buddha, dan 
Khonghucu menyebut Thian atau Shang-ti. Namun apapun sebutan nama tuhan, sesungguhnya umat Baha'i meyakini bahwa tuhan yang disebut dengan nama yang berbeda ditujukan pada tuhan yang sama. Sebagian kecil mahasiswa tidak mempermasalahkan penyebutan tuhan karena hal tersebut juga dilakukan oleh penganut Yahudi yang tidak ingin menyebut nama tuhan secara langsung kecuali hanya melalui simbol huruf Y-H-WH.

Selain beberapa mahasiswa yang memiliki kesamaan pendapat di atas, salah seorang mahasiswa menyebutkan bahwa pada umumnya umat Baha’i menyebut Tuhan mereka dengan sebutan "Tuhan" yang dalam bahasa Arab disebut dengan Allah. Penyebutan nama Tuhan atau Allah dalam agama Baha'i memang merupakan panggilan yang umum diberikan umat kepada tuhan. Salah seorang mahasiswa juga memiliki pendapat lain tentang konsep ketuhanan dalam agama Baha'i, bahwa agama Baha’i percaya Tuhan adalah Sang Pencipta alam semesta dan Dia bersifat tidak terbatas, tak terhingga, dan Maha Kuasa. Tuhan tidak dipahami dan manusia tidak bisa sepenuhnya memahami realitas Keilahian-Nya. Oleh karena itu, Tuhan telah memilih untuk membuat diri-Nya dikenal manusia melalui para rasul dan nabi, dalam hal ini bermanifestasi dalam wujud manusia, yaitu Baha'ullah.

\section{Konsep Kenabian atau Pembawa Wahyu}

Umat Baha'i mempercayai bahwa Tuhan telah memilih para nabi dan rasul untuk membuat diri-Nya dikenal umat manusia di dunia. Para nabi dan rasul tersebut ialah: Ibrahim, Musa, Krishna, Zoroaster, Buddha, Isa, Muhammad, dan Baha'u'llah. Para nabi dan rasul yang suci ini bagaikan cermin yang memantulkan sifat-sifat dan kesempurnaan Tuhan. Mereka merupakan saluran suci untuk menyalurkan kehendak Tuhan bagi umat manusia melalui Wahyu Ilahi yang terdapat dalam kitab-kitab suci umat beragama di seluruh dunia.

Penjelasan ini dinilai oleh sebagian kecil mahasiswa sebagai "kelucuan ajaran". Mahasiwa berpikir bahwa tidak ada satu agama pun di muka bumi ini yang menghimpun seluruh tokoh suci, nabi atau rasul sebagai utusan 
yang diyakini sebagai tokoh yang patut diimani secara bersama-sama atau keseluruhan.

Pada pengamatan dan kajian awal tentang agama Baha'i, hampir semua mahasiswa menilai bahwa Baha'ullah sebagai pembawa wahyu dan sekaligus perwujudan Tuhan merupakan sempalan atau aliran Islam menyimpang yang ada di daerah Iran. Umat Baha'i sendiri mempercayai bahwa Mirza Husein Ali atau sering dikenal dengan nama Baha'ullah yang berarti Kemuliaan Tuhan adalah pembawa wahyu agama Baha'i. Dia mengumumkan misinya untuk menciptakan kesatuan umat serta mewujudkan keselarasan di antara agama-agama yang ada di dunia pada tahun 1863. Pengumuman Baha'ullah atas misinya sekaligus menunjukkan bahwa agama Baha'i bukan merupakan aliran atau faham agama tertentu. Pada umumnya mahasiswa mengetahui bahwa agama Baha'i lahir di Persia (Iran), meskipun mereka berbeda pendapat dalam menyebutkan kapan agama ini lahir. Dalam hal ini ada yang mengatakan abad 19, bahkan ada yang menyebut Baha'i muncul pada awal abad ke 21.

Dalam sejarahnya dijelaskan bahwa Baha'ullah dijatuhi hukumam karena ajarannya, tetapi hal tersebut tidak membuat dia putus asa dalam menyebarkan agamanya, sebagaimana utusan Tuhan lainnya. Baha'ullah terus mengumumkan bahwa umat manusia kini berada pada ambang pintu zaman baru, yaitu zaman kedewasaan. Untuk pertama kalinya dalam sejarah, terbuka kemungkinan bagi setiap orang untuk melihat seluruh bumi dengan semua bangsanya yang beraneka ragam dalam satu perspektif.

Di antara stereotip mahasiswa yang penilaiannya cenderung sama adalah bahwa Baha'ullah menyamakan kebenaran semua agama. Hal ini berdasarkan pada ajaran Baha'ullah yang menyatakan semua agama berasal dari Tuhan yang sama dan mereka saling mengisi serta melengkapi. Semua utusan Tuhan mengajarkan Keesaan Tuhan dan mewujudkan cinta dalam kalbu-kalbu para hamba-Nya. Pada umumnya mahasiswa seperti "tidak siap" atau menyetujui bahwa semua agama berasal dari Tuhan yang sama. Mahasiswa menilai bahwa jika nama agamanya saja berbeda, maka tidak 
mungkin tuhannya adalah sama. Penilaian negatif mahasiswa pada ajaran Baha'i yang menawarkan keyakinan untuk saling melengkapi dan mengisi satu sama lain, disebutkan dengan satu istilah kecerobohan dan indikasi bahwa agama Baha'i tidak memiliki nilai lebih sehingga pemeluknya harus berbagi dan saling melengkapi ajaran satu sama lain. Mahasiswa meyakini bahwa kebenaran sebuah ajaran agama dapat dilihat dari keutuhan dan kelengkapan ajaran sebagaimana ajaran Islam yang dikatakan tuhan sebagai agama yang sempurna.

Setelah wafatnya pada tahun 1892 di Bahji yang berada di Tanah Suci, Baha'ullah menulis surat wasiat yang menunjuk putra sulungnya Abdul Baha' sebagai suri tauladan agama Baha'i dan sebagai penafsir yang sah atas tulisan sucinya, serta menjadi pemimpin agama Baha'i. Dalam sabdanya, Baha'ullah mengatakan bahwa kini saatnya telah tiba bagi setiap bangsa di dunia untuk menjadi anggota dari satu keluarga besar umat manusia. Selanjutnya, ia juga mengajarkan bahwa saatnya telah tiba untuk mewujudkan kesatuan umat manusia serta mendirikan suatu masyarakat sedunia. Dalam keterangan tentang silsilah kenabian, beberapa mahasiswa menyetujui dan tidak mempermasalahkan jika Baha'ullah mewasiatkan ajarannya untuk diteruskan oleh keluarganya sendiri. Hal ini dianggap mahasiswa memiliki kesamaan dengan silsilah kenabian dalam Islam, di mana sejarah menunjukkan beberapa nabi lahir dari satu keluarga tertentu. Namun sebagian besar mahasiswa menilai bahwa keinginan Baha'ullah agar ajarannya diteruskan kepada putera sulungnya adalah bentuk "kelemahan" dan indikasi bahwa sistem monarki kenabian seperti ini tidak lain hanyalah sebuah "modus" dari manusia biasa yang menginginkan kedudukan (derajat kenabian).

Abdul Baha' pada tahun 1911-1913 melakukan perjalanan ke Mesir, Eropa, dan Amerika untuk mengumumkan misi Baha'ullah mengenai kedamaian dan keadilan sosial kepada semua umat beragama kepada berbagai organisasi pendukung perdamaian, para pengajar di universitasuniversitas, para wartawan, pejabar pemerintah, serta khalayak umum lainnya. Pada umumnya mahasiswa merasakan keanehan dan sama sekali tidak percaya bahwa ada seorang utusan tuhan yang mengajar para dosen 
atau memberikan kuliah di universitas. Mahasiswa menilai bahwa apa yang dilakukan Baha'ullah bukan perbuatan seorang nabi, sebab Baha'ullah tidak jauh berbeda dengan tokoh masyakarat Cina, Khonghucu yang mengajarkan etika dan filsafat di masyarakat yang bobrok.

Pada tahun 1921, Abdul Baha' wafat. Dalam surat wasiatnya, ia menunjuk cucu tertuanya, Shoghi Effendi Rabbani, sebagai Wali Agama Baha'i dan Penafsir ajaran agama ini. Shoghi Effendi menerjemahkan banyak tulisan suci Baha'ullah dan Abdul Baha' ke dalam Bahasa Inggris dan menjelaskan makna dari tulisan-tulisan suci tersebut selama hidupnya hingga ia wafat pada tahun 1957. Setelah wafatnya Shoghi Effendi, demi melanjutkan amanat dari Baha'ullah, umat Baha'i membentuk Balai Keadilan Sedunia yang dibimbing oleh lembaga internasional.

Penyebutan istilah Wali Agama, oleh beberapa mahasiswa dianggap tidak dikenal dalam agama Islam. Namun sebagian besar menilai bahwa istilah Wali Agama atau Penafsir yang dinisbatkan kepada Shogi Effendi mungkin dapat disamakan dengan istilah waliyullah atau mufasir di dalam Islam. Sementara pada penyebutan Balai Keadilan Sedunia, mahasiswa menilainya semacam Majelis Ulama Indonesia (MUI). Stereotip mahasiswa pada konteks Balai Keadilan Sedunia tidak mengarah pada penilaian negatif, dalam hal ini kebanyakan hanya menghubungkannya dengan MUI tanpa terlebih jauh memberikan penilaian.

Pada sesi outing class mahasiswa bersama tokoh agama Baha'i Pontianak, di antaranya Elfian, Handoko, Risda, dan Rofiq dijelaskan bahwa agama Baha'i masuk ke Indonesia pada tahun 1878 M melalui pedagang Persia, Turki yang bernama Jamal Effendy dan Mustafa Rumi di Sulawesi. Di Kalimantan Barat sendiri, tokoh yang mengenalkan agama Baha'i adalah seseorang yang berasal dari Maluku dan sekarang penganutnya berjumlah 16 orang. Pendapat lain mengatakan bahwa pembawa agama Baha'i di Kalimantan Barat yang pertama adalah seorang dokter dari Iran, sementara pemeluk pertama agama Baha'i di Kalimantan Barat adalah seorang tentara (tanpa menyebutkan nama) yang berasal dari Surakarta yang kala itu sedang bertugas di Sintang. 
Dalam hubungannya dengan pembawa ajaran Baha'i, salah seorang mahasiswa menilai bahwa sebenarnya agama Baha'i bisa dengan mudah menyebar di tanah air, karena konsep agama Baha'i cenderung tidak mengucilkan agama lain bahkan mengakui keberadaan agama lainnya, tetapi agama ini tidak memiliki sejarah agama yang sempurna. Mahasiswa menjelaskan bahwa dibandingkan dengan Islam yang memiliki catatan sejarah perkembangan yang sangat menakjubkan, sementara agama Baha’i dinilai tidak memiliki informasi yang memadai tentang asal usul, sejarah dan perkembangannya di sebuah daerah. Selanjutnya mahasiswa menyarankan perlunya penelitian yang khusus mengkaji aspek-aspek historis eksistensi agama Baha'i di sebuah daerah.

Selain itu, pendapat lain mengatakan bahwa agama Baha'i adalah agama baru, yang kedatangannya tidak bisa langsung diterima begitu saja oleh masyarakat. Masih banyak masyarakat yang masih merasa asing dengan keberadaan agama Baha'i, bahkan ada mahasiswa yang beranggapan bahwa agama Baha'i adalah agama yang sesat. Menurut beberapa mahasiswa, di Indonesia, agama Baha’i belum secara sah dinyatakan oleh pemerintah sebagai sebuah agama.

\section{Konsep Kitab Suci}

Kitab Suci yang menjadi pedoman dan tuntunan hidup umat Baha'i adalah al-A'das, ada juga yang menyebutnya dengan al-Aqdas. Al-Aqdas ditulis oleh Baha'ullah dan telah diterjemahkan ke dalam 802 bahasa, disesuaikan dengan perkembangan pengikutnya yang telah tersebar di seluruh dunia. Di dalamnya berisikan tulisan mengenai keesaan Tuhan dan fungsi Wahyu Ilahi; tujuan hidup; ciri dan sifat roh manusia; kehidupan di alam Ilahi sesudah mati; hukum-hukum dan prinsip-prinsip agama; ajaranajaran akhlak; perkembangan kondisi dunia serta masa depan umat manusia. Selain dituntun oleh al-Aqdas, umat Baha'i juga dibimbing oleh buku-buku dan surat-surat yang ditulis oleh Abdul Baha' dan Shoghi Effendi.

Pada umumnya mahasiswa memahami secara sederhana tentang isi ajaran Baha'i yang tertuang dalam kitab al-Aqdas, karena diakui oleh 
mahasiswa tidak ada satu pun di antara mereka yang pernah melihat atau mengetahui kitab suci ini. Beberapa mahasiwa bahkan menyatakan bahwa mereka baru mengetahui bahwa agama Baha'i memiliki kitab suci yang bernama al-Aqdas atau al-A'das.

Berhubung secara prinsip mahasiswa berhadapan dengan "orang asing" atau keyakinan bukan Islam, penilaian mahasiswa terhadap kitab suci diselimuti keraguan dan bahkan pernyataan bahwa kitab suci tersebut bukan merupakan wahyu Tuhan, tapi ciptaan atau karangan pribadi Baha'ullah. Meskipun mahasiswa mengaku belum pernah melihat secara langsung kita suci dan isinya, mahasiswa secara spontan menilai dan mengklaim bahwa kitab suci al-Aqdas tidak bisa dijadikan pedoman hidup. Secara sederhana dan mungkin terkesan menyederhanakan, mahasiswa beralasan jika kitab suci tersebut merupakan kitab yang diwahyukan, mengapa mereka (umat Islam) atau mungkin umat yang lain tidak mengenal kitab al-Aqdas ini. Jika kitab ini ditujukan untuk semesta alam, mestinya kitab tersebut telah sampai ke masyarakat secara luas untuk dapat dipedomani atau minimal dikaji kebenaran ajarannya.

Sebagian mahasiswa yang tidak mempermasalahkan kebenaran atau keabsahan kita suci Baha’i menyebutkan bahwa di dalam kitab sucinya umat Baha'i ada wahyu ilahi "Sabda Tuhan" yang dapat membuka potensi rohani setiap individu serta membantu umat manusia berkembang terusmenerus manuju potensinya yang tertinggi. Artinya, terlepas dari apakah kitab suci ini asli atau palsu, kitab suci Baha’i dinilai memiliki kebenaran dan manfaat atau keutamaan bagi yang meyakininya.

\section{Konsep Tempat Ibadah}

Rumah ibadah agama Baha'i mencerminkan tujuan dasar agama Baha'i yang mendorong kesatuan umat manusia dan mencerminkan keyakinan akan keesaan Tuhan. Rumah ibadah dipersembahkan kepada Tuhan Yang Maha Esa dan dijadikan sebagai "tempat terbit pujian kepada Tuhan." Rumah ibadah agama Baha'i dapat digunakan oleh semua umat beragama untuk melaksanakan ibadah sesuai dengan keyakinannya masing-masing. 
Seringkali tempat ibadah dipergunakan untuk melaksanakan doa bersama antar umat beragama.

Dalam konteks perbedaan budaya, mahasiswa menilai hal di atas sebagai "sesuatu yang tidak masuk akal," dan mereka meragukan hakikat dari sebuah tempat ibadah yang mestinya ditujukan untuk satu tuhan lalu tiba-tiba dapat dilakukan penyembahan secara bersama-sama pada "tuhan yang berbeda." Tentu saja ini sebuah ketidaklaziman dalam konteks tradisi beragama yang memiliki panduan dan ajaran khusus bagaimana memperlakukan dan memaknai sebuah tempat suci. Bagi umat Islam, masjid adalah tempat di mana seorang hamba bersujud menyembah dan berdoa pada Rabb-nya. Sementara gereja diyakini sebagai tempat persatuan manusia dengan tuhan, karena gereja dipahami sebagai tubuh kristus. Pemahaman yang berbeda pada tiap agama dianggap mahasiswa sebagai jurang pemisah keyakinan pada satu tempat ibadah digunakan oleh sekian banyak keyakinan yang berbeda.

Rumah ibadah umat Baha'i tersebar di seluruh dunia, mulai dari New Delhi-India, Panama City-Amerika Tengah, Frankfurt, Jerman, Apia, Samoa Barat-Pasifik, Wilmette, Illionis-Amerika Serikat, Kampala Uganda-Afrika, Sydney-Australia, Santiago, dan Chile Amerika Latin. Dalam arsitektur bangunannya, setiap rumah ibadah umat Baha’i memiliki ciri yang sama, yakni memiliki Sembilan pintu. Pendapat lain menyatakan bahwa ciri-ciri yang sama yang terdapat dalam setiap bangunan tempat ibadah umat Baha'i adalah tempat ibadah itu harus memiliki sembilan sisi dan sebuah kubah di tengahnya. Di dalam tempat beribadah umat Baha'i, terdapat berbagai macam kitab suci dari semua agama. Hal ini bertujuan agar semua umat beragama bisa melaksanakan peribadatan di rumah ibadah umat Baha'i. Inilah yang dinilai mahasiswa sebagai ajaran yang "tidak memiliki ciri khas" karena seolah-olah membenarkan semua keyakinan agama.

\section{Beberapa Bentuk Ibadah}

Umat Baha’i diwajibkan untuk melaksanakan ibadah seperti sembahyang, berpuasa, dan berdoa, sebagaimana sabda Baha'ullah: 
"Sembahyang wajib bersifat mengikat, karena mengakibatkan kerendahan hati serta kepatuhan, menyebabkan orang menghadapkan wajahnya kepada Tuhan dan mengungkapkan cinta kepada-Nya. Melalui sembahyang itu, manusia berhubungan dengan Tuhan, berupaya mencapai kedekatan dengan-Nya, bercakap-cakap dengan Kekasih hatinya, serta mencapai derajat-derajatnya rohaniah."

"Doa dan puasa adalah penyebab kesadaran dan kewaspadaan dan mendatangkan perlindungan dan pemeliharaan dari cobaan."

Umat Baha’i melaksanakan ibadah dalam tiga bagian: sembahyang jangka pendek, sembahyang jangka menengah, dan sembahyang jangka panjang. Sembahyang jangka pendek waktunya satu kali, yakni pada tengah hari sampai waktu terbenam matahari. Sembahyang menengah pada tiga waktu, dimulai pada pagi hari sampai tengah hari, tengah hari sampai terbenam matahari, dan terbenam matahari sampai terbit matahari. Sedangkan sembahyang panjang waktunya bebas.

Dari ketiga bagian sembahyang umat Baha'i ini, mereka hanya diperbolehkan memilih salah satu proses sembahyang dalam sehari yang disesuaikan dengan kemampuan mereka. Karena agama Baha'i adalah agama yang berasal dari Timur Tengah, tata cara ibadahnya pun sedikit mirip dengan agama Islam dan Kristen. Baha’i bersembahyang dengan takbir, rukuk, dan sujud dengan membaca doa tertentu menurut keyakinan mereka. Kiblatnya menghadap ke arah 45 deratat ke Barat menghadap ke Israel.

Sebagian besar mahasiswa menilai bahwa konsep ibadah agama Baha’i "meniru" konsep ibadah ajaran Islam. Hal ini dilihat dari beberapa nama ibadah yang sama seperti puasa, doa, sembahyang, dan lain-lain dengan tujuan dan gerakan yang hampir sama. Umat Baha'i juga mengenal istilah "berzakat" sebesar $19 \%$ dari harta yang dimiliki. Memang jika dibandingkan ukurannya dengan zakat dalam Islam (sebesar 2.5\%) tentu nilai zakat pada agama Baha'i tergolong sangat besar. Namun kemiripan ajaran seperti mengeluarkan harta untuk dizakatkan adalah contoh adanya kesamaan antara Islam dan Baha'i. Begitupun dalam ritual ibadah sembahyang yang dijelaskan memiliki kemiripan gerakan dengan ibadah 
salat dalam Islam yang terdiri dari takbir, rukuk, dan sujud dengan membaca doa tertentu. Sementara dalam hal penentuan kiblat, meskipun berbeda arah, di mana Islam menghadap kiblat di Mekkah sedangkan Baha'i menghadap Israel, tempat dimakamkannya Baha'ullah, namun penentuan tempat suci tertentu untuk menetapkan haluan ibadah memiliki kemiripan.

\section{Konsep Hari Raya}

Sebagian besar mahasiswa menilai hari raya umat Baha'i juga merupakan rentetan "penjiplakan" terhadap ajaran Islam yang mengajarkan puasa dan hari raya di waktu yang berdekatan, meskipun dengan jumlah hari dan sebab perayaan yang berbeda. Umat Baha'i merayakan Hari Raya Nauruz yang jatuh pada setiap tanggal 21 Maret. Sebelum merayakan Nauruz, umat Baha'i terlebih dahulu diwajibkan berpuasa selama 19 hari penuh. Beberapa hari raya lainnya yang diyakini umat Baha'i seperti Deklarasi Bâb, Hari Raya Ridwan (I, IX, XII), Lahirnya Bâb, Lahirnya Baha'ullah, dan Wafatnya Baha'ullah.

Pada bagian ini, mahasiswa umumnya tidak mempermasalahkan adanya ritual atau perayaan hari raya dengan momen yang dihubungkan dengan tradisi atau keyakinan suatu agama. Namun hal yang mahasiswa nilai sebagai sebuah "penjilpakan" adalah perayaan hari raya yang didahului oleh ritual ibadah puasa meskipun dengan jumlah hari yang berbeda (19 hari).

Menurut ensiklopedi Wikipedia, hari raya Nauruz, Norouz atau Nowrouz berasal dari bahasa Persia yang merupakan perayaan tahun baru tradisional masyarakat Iran, Azerbaijan, Afganistan, Pakistan dan India, dan suku Kurdi. Sebagai sebuah perayaan musim semi menyambut awal kalender Iran, umat Baha’i memperingati dan merayakan Nawruz sebagai sebuah ritual ibadah meskipun ritual ini bersifat turun temurun sejak ribuan tahun yang lalu. Untuk melengkapi perayaan Nawruz, umat Baha'i melaksanakan ibadah puasa selama 19 hari. Ibadah puasa dimaksudkan agar umat dididik untuk menahan nafsu, agar dapat menjadi teladan bagi lingkungan karena keberhasilannya membangun rohani secara baik. Pada 
usia 15 tahun, umat Baha'i sudah diwajibkan berpuasa, kecuali bagi yang sakit, haid, menyusui, bekerja berat atau yang berusia di atas 70 tahun.

Ketentuan yang disebutkan di atas memiliki banyak kemiripan dengan ajaran puasa di dalam Islam, baik dari tujuan berpuasa maupun ketentuan atau syarat-syarat berpuasa. Mahasiswa menilai bahwa banyaknya kemiripan ibadah dari agama Baha'i dengan agama Islam ini disebabkan karena Baha'ullah pada awalnya beragama Islam, tinggal dan hidup dilingkungan Muslim dan memiliki keturunan keluarga Muslim sehingga diperkirakan ajaran-ajaran Islam memiliki pengaruh signifikan terhadap keyakinan dan ajaran agama Baha'i.

\section{Konsep Ajaran secara Umum}

Agama Baha'i adalah agama yang berdiri sendiri tanpa mengikuti sekte dari agama lain meskipun pembawa wahyunya besar di lingkungan sekte Shîah Islam. Agama Baha'i merupakan agama yang bersifat universal. Penganut Agama Baha'i berkeyakinan bahwa agama harus menjadi sumber perdamaian dan keselarasan, baik dalam kehidupan berkeluarga, bermasyarakat, berbangsa maupun dunia. Umat Baha'i dikenal sebagai sahabat bagi para penganut semua agama, karena melaksanakan keyakinan ini secara aktif. Agama Baha’i bertujuan untuk melindungi kepentingankepentingan umat manusia dan memajukannya, serta untuk memupuk semangat cinta kasih dan persahabatan diantara manusia.

Meskipun disebutkan bahwa agama Baha'i merupakan agama yang berdiri sendiri, sebagian besar mahasiswa meyakini bahwa Baha'i merupakan pecahan dari Islam karena berasal dari lingkungan sekte Shîah yang secara historis berasal dari Islam.

Agama yang bisa disebut dengan agama monoteistik ini menekankan pada kesatuan spiritual bagi seluruh umat manusia, karena Baha'îyah atau Baha'isme ini menyatukan atau menggabungkan agama-agama dari agama Yahudi, Nasrani, Islam, dan agama lainnya menjadi satu. Pernyataan ini dijelaskan oleh salah seorang mahasiswa sebagai agama yang mencampur adukkan keyakinan. Menurut mahasiswa, tidak mungkin semua agama 
berkumpul menjadi satu kesatuan dengan Tuhan yang sama, karena konsep keyakinan tentang tuhan juga berbeda satu dengan yang lain.

Semua manusia adalah satu dan setara dihadapan Tuhan dan mereka harus diperlakukan dengan baik, harus saling menghargai dan menghormati. Segala bentuk prasangka baik ras, suku bangsa, agama, warna kulit, jenis kelamin, dan lain-lain harus dihilangkan. Prasangka merupakan penghalang terbesar bagi terwujudnya suatu kehidupan yang damai dan harmonis di dalam suatu masyarakat yang beraneka ragam. Dalam konsep di atas, pada umumnya mahasiswa sepakat dan sependapat dengan perlunya saling menghormati antar keyakinan, meskipun tidak berarti dipahami sebagai untuk saling membenarkan dan menyamakan keyakinan satu dengan yang lainnya.

Manusia adalah buah-buah dari satu pohon dan daun-daun dari satu dahan. Meskipun berbeda satu sama lain secara jasmani dan perasaan, meskipun memiliki bakat dan kemampuan yang berbeda-beda, namun buah dan daun tumbuh dari satu akar yang sama, begitu pula dengan manusia, meskipun berbeda-beda namun berasal dari Tuhan yang satu, semua manusia adalah satu. Konsep Baha'i ini cenderung dipahami secara beragam oleh mahasiswa, sebagian sependapat, sebagian yang lain tidak setuju dengan argumen masing-masing. Kelompok mahasiswa yang mendukung konsep ini mengacu pada ajaran Islam tentang ruh yang ditiupkan ke dalam diri manusia berasal dari Tuhan. Sedangkan mahasiswa yang tidak sependapat menyebutkan bahwa manusia diciptakan dengan keunikan dan ciri khas masing-masing sehingga tidak bisa disebutkan bahwa manusia itu satu.

Umat Baha'i mempercayai bahwa orang-orang yang dianugerahi dengan keikhlasan dan iman, seharusnya bergaul dengan semua kaum dan bangsa di dunia dengan perasaan gembira dan hati yang cemerlang. Oleh karena itu, bergaul dengan semua orang telah membantu memajukan dan akan terus memajukan persatuan dan kerukunan, yang pada gilirannya akan membantu memelihara ketentraman di dunia serta memperbaharui bangsa-bangsa. 
Baha'ullah mewajibkan kepada setiap orang tua untuk mendidik anakanak mereka, baik perempuan maupun laki-laki. Di samping pelajaran keterampilan, keahlian, seni, ilmu pengetahuan, dan yang paling diutamakan adalah pendidikan akhlak dan moral. Tanpa pendidikan, seseorang tidak mungkin mencapai seluruh potensinya atau memberikan kontribusi positif kepada masyarakat. Oleh karena itu, pendidikan haruslah universal dan wajib bagi semua.

Harus tersedia kesempatan yang sama bagi perkembangan perempuan dan laki-laki, terutama kesempatan yang sama dalam memperoleh pendidikan. Perempuan dan laki-laki bagaikan dua belah sayap dari burung kemanusiaan. Perkembangan seluruh kemampuan dan potensi masyarakat hanya dapat diwujudkan bila kedua sayapnya itu sama kuatnya. Pendapat di atas diakui dan dibenarkan oleh semua mahasiswa.

Agama Baha'i bukanlah agama missioner, mereka tidak mencari pengikut, tetapi jika ada yang ingin masuk ke dalam agama mereka, mereka sangat menerima dan terbuka. Seseorang yang ingin menjadi pemeluk Agama Baha'i tetapi telah memiliki agama sebelumnya diperbolehkan untuk masuk ke Agama Baha'i tanpa meninggalkan agama sebelumnya. Hal ini dikarenakan umat Baha'i menjunjung tinggi arti persatuan dan kesatuan dalam kehidupan umat beragama di seluruh dunia. Mahasiswa memahami konsep ini sebagai hal yang lumrah dan dapat dibenarkan. Adapun syarat untuk menjadi pemeluk Baha'i, seseorang diharuskan mengucapkan kalimat Allâh 'Abhâ Bahầ' al-Abhâyang berarti "kemuliaan dari segala kemuliaan”, maka dia telah menjadi pemeluk agama Baha’i. Hal ini dipahami mahasiswa serupa dengan dua kalimat syahadat yang ada dalam Islam. Beberapa kalimat lain yang memiliki kesamaan adalah pengucapakan kata basmalah, jika dalam agama Baha’i ialah bismika baby alabhâ yang berarti "dengan menyebut nama dia dari segala kemuliaan." Mahasiswa tidak mempermasalahkan konsep tersebut karena hanya merupakan pemindahan dari nama Allah ke nama Baha'ullah.

Stereotip mahasiswa jurusan Komunikasi dan Penyiaran Islam (KPI) Fakultas Ushuluddin, Adab, dan Dakwah setelah mengikuti mata kuliah 
Komunikasi Lintas Agama di IAIN Pontianak mengalami perubahan signifikan setelah peneliti melakukan post test pada pertemuan terakhir. Meskipun ada beberapa mahasiswa yang belum begitu memahami secara utuh konsep keagamaan Baha'i, namun sebagian besar mahasiswa peneliti telah mengalami perubahan penilaian yang jauh lebih baik.

Menurut Sarlito W. Sarwono, "stereotip merupakan komponen kunci dari prasangka. Stereotip adalah kerangka kognitif yang berisi pengetahuan dan belief tentang kelompok sosial tertentu dan dilihat sebagai tipikal yang dimiliki oleh anggota kelompok tertentu tersebut." ${ }^{\prime 2}$ Seseorang yang memiliki stereotip terhadap orang lain atau kelompok sosial lain akan melihat kelompok tersebut memiliki ciri-ciri tertentu walaupun dalam intensitas bahkan respek yang rendah. Jika peneliti telusuri beberapa penyebab munculnya stereotip mahasiswa, dan dihubungkan dengan pengaruh mata kuliah Komunikasi Lintas Agama, maka dapat dianalisa beberapa aspek sebagai berikut:

Pertama: Ketika stereotip dihubungkan dengan konteks "orang asing" atau pihak luar, maka penilaian mahasiswa terhadap agama Baha'i mengarah pada kesimpulan bahwa agama Baha'i adalah agama yang menyimpang dari ajaran Islam dan sudah tidak bisa lagi disebut sebagai umat Islam. Meskipun pada awalnya mahasiswa menduga bahwa Baha'i memiliki latar belakang keluarga muslim Shîah, namun setelah menilai faham dan ajaran Baha'ullah, mahasiswa beranggapan bahwa Baha'i bukan bagian dari Islam. Klaim sebagian besar mahasiswa ini sebenarnya sama sekali tidak berpengaruh terhadap posisi agama Baha'i yang memang bukan merupakan bagian atau aliran dari agama Islam. Namun yang patut dilihat adalah penilaian yang diberikan mahasiswa mengacu pada titik tekan istilah "menyimpang" lalu selanjutnya memutuskan bahwa Baha'i bukan kelompok kami. Dalam konteks ini maka stereotip mahasiswa terhadap agama Baha'i dengan jelas menunjukkan adanya kesalahpahaman

12 Sarlito M. Sarwono dan Eko A. Meinarno (eds.), Psikologi Sosial (Jakarta: Salemba Humanika, 2009), 228. 
dalam menilai pokok-pokok ajaran Baha’i dan status kedudukan agama Baha'i yang memang sama sekali bukan berasal dari ajaran Islam.

Kedua: Dalam konteks perbedaan budaya, sterotip yang terbangun melalui penilaian mahasiswa lebih sering tampak sebagai upaya menjelaskan agama lain dari sudut pandang agamanya sendiri. Munculnya penilaian bahwa agama Baha’ melakukan "penjiplakan", "peniruan", "agama yang tidak masuk akal", "agama modus", dan bentuk-bentuk stereotip lain karena kebanyakan mahasiswa lahir dari kondisi lingkungan yang tidak memberikan pemahaman yang cukup tentang agama selain Islam. Hal ini terlihat dari beberapa mahasiswa yang mencoba memberikan penilaian yang sifatnya menyederhanakan dan seperti "memaksakan" pandangannya sendiri pada agama Baha'i. Akibatnya, beberapa konsep dasar keagamaan Baha'i diklaim atau divonis sebagai upaya untuk meniru ajaran Islam.

Setelah mahasiswa mengikuti mata kuliah Komunikasi Lintas Agama, khususnya ketika mereka dipertemukan langsung dengan narasumber dari pengikut Baha'i, mahasiswa mengalami perubahan cara pandang dan penilaian terhadap Baha'i dengan sangat signifikan. Hal ini terlihat dari pengakuan sebagian besar mahasiswa yang mengakui kekeliruannya dalam memahami beberapa ajaran Baha'i. Beberapa mahasiswa menyatakan kepuasannya setelah bertemu langsung dengan narasumber Baha'i yang diklaimnya memperbaiki penilaian yang selama ini telah terbangun di pemikiran mahasiswa.

\section{Penutup}

Berdasarkan temuan dan paparan penelitian di atas, maka dapat disimpulkan beberapa hal sebagai berikut: 1). Stereotip atau penilaian seseorang terhadap agama lain (seperti agama Baha'i) ditentukan oleh persepsi yang dibangun oleh pengetahuan atau informasi yang didapatkannya. Mahasiswa Jurusan Komunikasi dan Penyiaran Islam Fakultas Ushuluddin, Adab, dan Dakwah Institut Agama Islam Negeri (IAIN) Pontianak mendapatkan pengetahuan tentang agama Baha'i melalui perkuliahan mata kuliah Komunikasi Lintas Agama baik melalui 
tatap muka di kelas maupun outing class di komunitas Baha'i di Pontianak Kalimantan Barat. Adapun bentuk stereotip yang muncul menunjuk pada kategori "orang asing" atau pihak yang berada diluar komunitas agama tertentu, sehingga penilaian yang diberikan mahasiswa mengacu pada titik tekan istilah "menyimpang" lalu selanjutnya memutuskan bahwa Baha'i bukan kelompok Islam; 2) dalam bentuk yang lain dari stereotip mahasiswa yaitu konteks perbedaan budaya, mahasiswa membangun penilaian terhadap agama lain dari sudut pandang agamanya sendiri. Beberapa istilah yang muncul sebagai bentuk stereotip mahasiswa terhadap agama Baha'i seperti menyebut istilah "penjiplakan", "peniruan", "agama yang tidak masuk akal", "agama modus", disebabkan pemahaman yang tidak memadai tentang agama selain Islam. Akhirnya, mahasiswa terkesan menyederhanakan bahkan seperti "memaksakan" pandangan nya sendiri pada agama Baha'i.

\section{Daftar Pustaka}

Bryant, Jennings, and Dolf Zillmann. Media Effect: Advances in Theory and Research. London:L. Erlbaum, 2002.

Fox, James. "Dimensi Waktu dalam Penelitian Sosial: Suatu Studi Kasus di Pulau Roti." Dalam Aspek Manusia dalam Penelitian Masyarakat, eds. Koentjaraningrat dan Donald K. Emmerson. Jakarta: Gramedia, 1982.

Gudykunst, W. B., and Y. Y. Kim. Communicating with Strangers: An Approach to Intercultural Communication. New York: McGraw-Hill, 1997.

Hudayana, Bambang. "Pengumpulan dan Analisis Data dalam Penelitian Etnografi." Jurnal Penelitian Agama, no. 2 (September-Desember, 1992).

Ju Lan, Thung. "Etnis Tionghoa Dalam Pemberitaan Media; Menghapus Prasangka dan Diskriminasi Etnis Dalam Pemberitaan Media Cetak."Makalah Seminar Yayasan KIPPAS, Novotel Soechl Medan, 21 Maret 2002.

Majelis Rohani Nasional Baha’i Indonesia. Agama Babai. Jakarta: Majelis Rohani Nasional Baha'i Indonesia, 2013. 
Moloeong, Lexy. Metodologi Penelitian Kualitatif. Bandung: Remaja Rosdakarya, 2002.

Nuhrison, M. "Eksistensi Agama Baha'i, Tao dan Sikh di Indonesia." Makalah Seminar Penelitian yang Diadakan oleh Puslitbang Kehidupan Keagamaan Badan Litbang dan Diklat, Kementerian Agama RI, Jakarta 22 September 2014.

Robbins, Stephen P. and Timothy A. Judge. Organizational Behavior. Prentice Hall, 2010.

Sarwono, M. Sarlito dan Eko A. Meinarno (eds.). Psikologi Sosial. Jakarta: Salemba Humanika, 2009.

Spradley, J. Metode Etnografi. Yogyakarta: Tiara Wacana, 1997.

Suparyogo, Bambang dkk. Metodologi Penelitian Agama. Jakarta: Grafika, 2001. 